\title{
REAL ESTATE SECTOR IN THE FACE OF CLIMATE CHANGE ADAPTATION IN MAJOR POLISH CITIES
}

\author{
Beata Wieteska-Rosiak \\ The Faculty of Economics and Sociology \\ University of Lodz \\ e-mail: beata.wieteskarosiak@uni.lodz.pl
}

\begin{abstract}
This paper aims to review subject-matter literature and analyse the development policy documents of major Polish cities addressing the issue of climate change adaptation (urban adaptation plans, Polish abbr. MPA) and concerning the real estate sector; it is also an attempt to draw conclusions and identify potential benefits and challenges that the construction sector is currently facing. The literature focuses on coastal real estate, costs, benefits and barriers in the adaptation of buildings. MPAs point to the significant role of the real estate sector in adapting to climate change. Soft and hard instruments are becoming increasingly important in MPA. These are spatial planning (building restrictions in hazardous areas, use of green roofs in investments), a system of incentives for investors to promote adaptation activities, ecological education, investments in improving the energy efficiency of buildings. Also identified are the benefits to the real estate sector, e.g. the growing importance of occupations on the real estate market, the development of innovations and increased access to cheaper services and technologies. In Polish cities, high-intensity residential areas are characterized by high sensitivity. MPAs will strengthen the resilience of the city's technical infrastructure and public space, as well as develop blue and green infrastructure, which may translate into the increased resilience of real estate.
\end{abstract}

Key words: resilience, extreme weather phenomena, buildings, local policy.

JEL Classification: Q01, O18, R00, R31, R33.

Citation: Wieteska-Rosiak, B. (2020). Real estate sector in the face of climate change adaptation in major polish cities. Real Estate Management and Valuation, 28(1), 51-63.

DOI: https://doi.org/10.2478/remav-2020-0005

\section{Introduction, Goal of the Study and Literature Review}

Advancing climate change has become one of the key global challenges and subjects debated at international fora. According to the Intergovernmental Panel on Climate Change, both natural and anthropogenic factors contribute to climate change (IPCC 2018). Principal greenhouse gas emitters are: construction, transport and manufacturing sectors.

Climate change has intensified the occurrences of extreme weather phenomena, which may cause damage to human life, health, assets, cultural heritage, the economy, and the natural environment. In other words, nature can potentially inflict material damage on residential buildings, offices, and buildings housing public institutions. This is somehow paradoxical; greenhouse gas emissions from buildings accelerate climate change and, by the same token, increase the risk of losses in urban neighborhoods.

Reduction of greenhouse gas emissions from anthropogenic sources has become a long-term objective of the EU development policy (European Commission, 2018) also adopted by the Polish government (Ministry Of Regional Development, 2012). It is a response to the reduced socio-economic 


\section{S sciendo}

development pressure exerted, also by the construction sector, on the natural environment. Recently, climate change adaptationhas gained importance in addition to the climate change mitigation policy. Since the real estate sector is threatened by climate change, its resilience should be reinforced, requiring the identification of directions, instruments, possibilities and types of adaptation activities.

Subject-matter literature discusses investor adaptation strategies, awareness as to the need to adapt buildings, costs of adaptation, barriers that determine climate change adaptation decisions, the need for innovation, and the impact of climate change on real estate in agriculture and tourism (Bunten \& Kahn, 2017; Fu et al., 2016; Andréa et al., 2016; Nunes, Souza \& Harari, 2017; Chouinard, Rabeniaina \& Weissenberger, 2013; Nolon, 2015; Veelen, 2016; Mcnamara \& Keeler, 2013; Chouinard, 2013; Parkinson, 2009; Mcalpine \& Porter, 2018; Warren-Myers et al., 2018; Binbin \& Jie, 2018; Mcnamara et al., 2018; Bisaro \& Hinkel, 2018). There is a visible lack of publications that make for a comprehensive review of the existing subject-matter literature, and the numerous issues and concrete studies discussed. Also, there is a deficit of publications focused on the content of Polish urban adaptation plans (Polish abbr. MPA) and how they relate to the real estate sector.

This paper aims to construct an overview of the subject-matter literature and examine development policy documents of major Polish cities that tackle climate change adaptation (also urban adaptation plans, MPAa) and, directly or indirectly, concern the real estate sector. It is also an attempt to draw conclusions and identify potential benefits and challenges facing the modern construction sector.

The paper analyzes the subject-matter literature and makes a list of current research studies which consider climate change adaptation and the real estate sector. It draws from the content of the urban adaptation plans of major Polish cities. Cities whose population exceeds $100 \mathrm{~K}$ are currently finetuning (social consultations, implementation) their urban adaptation plans (MPA), to which they are obliged by a document titled Strategiczny plan adaptacji dla sektorów i obszarów wrażliwych na zmiany klimatu do roku. 2020 z perspektywa do roku 2030 [Strategic Adaptation Plan for Sectors and Areas Vulnerable to Climate Change until 2020 and an Outlook for 2030] (Ministry Of Environment, 2012). Challenges faced by cities in the context of climate change adaptation are heralded by the National Urban Policy 2023 (Ministry Of Infrastructure And Development, 2015). Cities are crucial development areas in regions and countries; they are places which concentrate people, innovation, buildings, infrastructure, transport, business, as well as social, economic, and environmental problems. Due to the concentration of different resources and the role cities play in development, adaptation of urban territories becomes critical.

The following research hypothesis and questions have been formulated for the purpose of this work:

Research hypothesis: The increased prominence of the adaptation policy and the intensity of occurrences increase the role played by the real estate sector in climate change adaptation in urban areas.

Research questions:

1) What is the place of the real estate sector on the climate change adaptation agenda in foreign literature?

2) What extreme weather phenomena pose a danger to the real estate sector and how?

3) How does the projected climate change adaptation policy in cities account for the real estate sector?

4) What opportunities and threats for the real estate sector are highlighted in the development policy in the face of climate change?

\section{Research Methodology}

Two research methods were deployed in these studies. The first one was a systematic literature review. The Tranfield methodology is readily used in systematic literature analysis (Tranfield et al., 2003; Denyer \& Tranfield, 2009). The methodology consists of several stages that were implemented in the research and described below.

Recent years have witnessed an increasing interest in the field of adapting cities to climate change, which is only confirmed by numerous publications featured in databases. ${ }^{1}$ Researchers are interested mainly in climatic hazards, their consequences to socio-economic development, climate policy, adaptation policy, costs, and directions of climate research.

${ }^{1}$ EBSCO database: adaptation, climate change, cities - 2,433 research papers. 
These studies are founded on the identification of publications simultaneously addressing climate change adaptation and the real estate sector. The following Internet platforms, providers of research databases, were used in this exercise: EBSCO, Emerald, Scopus, Web of Science, and Wiley Online Library. These are well-known research databases holding high quality research and scientific content. Since the subject of the paper is not extensively discussed in literature, a decision was made to analyze a bigger number of databases. All databases were searched for publications including the following terms in their abstracts:

1) adaptation,

2) climate change,

3) real estate or real estate sector or construction industry or construction sector.

Attention was paid to peer-reviewed (scholarly) journals only. As we investigated into a rather fresh topic, no time limit was imposed in order to identify as many papers as possible. In the 1990s, papers focusing on the issue in question emerged sporadically. They can be found most frequently in the period 2013-2018. Results of searches have been presented in Table 1.

Table 1

Results of searches for papers addressing real estate and climate change adaptation

\begin{tabular}{lccc}
\hline Database & $\begin{array}{c}\text { No. of } \\
\text { papers }\end{array}$ & $\begin{array}{c}\text { No. of papers excluding } \\
\text { overlapping content in } \\
\text { databases }\end{array}$ & $\begin{array}{c}\text { No. of papers directly addressing } \\
\text { climate change adaptation in } \\
\text { the real estate sector }\end{array}$ \\
\hline EBSCOhost & 35 & 34 & 27 \\
\hline Emerald & 0 & 0 & 0 \\
\hline Scopus & 11 & 2 & 13 \\
\hline Web of Science & 23 & 14 & 0 \\
\hline $\begin{array}{l}\text { Wiley } \\
\text { Library }\end{array}$ & 1 & 0 & 40 \\
\hline
\end{tabular}

Source: EBSCOhost, Emerald, Scopus, Web of Science, and Wiley Online Library databases. Author's own compilation.

The second method was desk research. We decided to examine documents included in urban adaptation plans of six Polish cities: Lodz, Gdansk, Krakow, Poznan, Wroclaw, and Warsaw, as these are the biggest cities in Poland and capital cities of regions. Such a choice allowed us to rather safely assume that the documents represent a multi-faceted approach to the issue due to complex development processes taking place in cities and the multiplicity of local actors (enterprises, residents, institutions). In most instances, the documents were MPA drafts submitted for social consultations. The analysis covered:

1) The city of Lodz climate change adaptation plan until 2030,

2) Gdansk climate change adaptation plan until 2030 - draft,

3) Krakow climate change adaptation plan until 2030 - draft,

4) The city of Poznan climate change adaptation plan until 2030,

5) The city of Wroclaw climate change adaptation plan until 2030 - draft,

6) Climate change adaptation strategy for the capital city of Warsaw until 2030 an outlook up to 2050. Assumptions for consultation,

7) Warszawski standard mieszkaniowy 1.2 [Warsaw housing standard 1.2] (draft for consultation), 2018 r.

These research methods allowed us to respond to the above stated research questions No. 1, 2, 3, and 4 . The research hypothesis has been positively validated.

\section{Research}

\subsection{Climate Change Adaptation in Real Estate Sector: Findings of Literature Review}

A systematic review of literature jointly addressing research studies on real estate and climate change adaptation helped to formulate preliminary conclusions. Firstly, we have recently observed a growing number of papers devoted to the subject in databases. Nevertheless, they are still rather scarce, which 


\section{S sciendo}

validates the selection of the research problem of this publication. When it comes to real estate adaptation, there is still a shortage of studies, cost and benefit analyses, adaptation efforts, identification of directions, and cooperation opportunities between the public and private sector.

Literature analyses revealed that research studies deal mostly with:

1) adaptation strategies pursued by investors and developers vis-á-vis coastal properties, the actors' awareness, cost of adaptation, demand and supply of coastal properties,

2) identification of factors and barriers that determine the decision-making factors and determinants of the implementation of adaptation efforts in real estate,

3) the role of real estate in climate change adaptation,

4) the need to create and absorb innovation that helps climate change adaptation,

5) tourist real estate and winter tourism in the context of reduced snowfall (Rutty et al., 2015; Scott, Dawson \& Jones, 2008),

6) agricultural real estate in the face of climate change (Darwin, 1999).

For ages, cities have been located in highly attractive locations in the proximity of water. Today climate change contributes to increased sea levels. The risk of flooding, i.e. the probability of flooding and damage to private and public assets, is rising (Mcalpine \& Porter, 2018; Warren-Myers et al., 2018).

The durability of resources, such as coastal properties, has been gaining importance (Bunten \& Kahn, 2017; Fu et al., 2016; Andréa et al., 2016; Nunes, Souza \& Harari, 2017; Chouinard, Rabeniaina \& Weissenberger, 2013; Nolon, 2015; Veelen, 2016; Mcnamara \& Keeler, 2013; Chouinard, 2013; Parkinson, 2009; Mcalpine \& Porter, 2018; Warren-Myers et al., 2018; Binbin \& Jie 2018; Mcnamara et al., 2018). The question arises how we can protect buildings and technical infrastructure from damage. Real property owners and administrators can choose between one of three solutions (Bunten \& Kahn, 2017; Veelen, 2016; Andréa et al., 2016).

The first solution assumes a passive approach of owners (administrators) who fail to adopt any adaptation measures. Its aim is to ensure surviving and to wait while as situation unfolds at its own speed. As a result, significant losses can be inflicted on public and/or private assets, as well as on the life and health of humans. The second one proposes leaving the property in question in the threatened area and adopting solutions that would directly target the building or its immediate vicinity. Measures proposed in this case include investment projects, such as elevating building foundations, resting buildings on piles, building floating houses, outfitting windows and doors with floodgates, constructing technical infrastructure (e.g., seawalls). The third solution consists in relocating buildings to safe areas to free up space for the rising sea. The move is motivated by the desire to reduce the exposure of resources, reduce losses in assets, and, above all, to provide space to accommodate flood waters and expand beaches (Bunten \& Kahn, 2017; Veelen, 2016; Andréa et al., 2016).

How real estate owners respond depends on many factors (Bunten \& Kahn, 2017) including financial (cost of relocation, cost and benefit analysis, real estate value, owner's financial standing, possibilities of applying for and receiving state aid), spatial (attractive areas available for relocation), social (awareness of existing hazards, emotional attachment to a particular location, behavioural aspects), economic (demand for vulnerable real estate, losses), and legal (policy pursued by the city, region, and central government, spatial planning) aspects.

Rising sea levels may decrease the demand and supply of coastal properties. Estimates show that coastal real estate prices and rental prices will fall. On the demand side, we will thus have less affluent households more vulnerable to climate change (Bunten \& Kahn, 2017). Subject-matter literature draws attention to the so called climate gentrification. The phenomenon appears to lead to a situation in which the most threatened areas in cities filled with buildings not adapted to climate change will accommodate lower income and low social status residents. On the other hand, areas and buildings adapted to climate change will become available to high income population (Keenan et al., 2018).

There are theoretical attempts made to develop models that would be helpful in finding out about cost-effectiveness of alternative solutions adopted in response to the rising sea levels (Fu et al., 2016), (NUNES, SOUZA \& HARARI, 2017). Depending on the strategy, we can identify different final costs and benefits to real estate owners, local authorities, and entire cities [Table 2]. The need to engage public and private funds in climate change adaptation is very strongly highlighted (Bisaro \& Hinkel, 2018; Warren-Myers et al., 2018). Only by making parallel efforts in both sectors can we expect the highest economic, social, and environmental benefits. 
Table 2

Costs and benefits of real estate relocation

\begin{tabular}{|c|c|}
\hline $\begin{array}{l}\text { Relocation costs to owners, society, } \\
\text { and city }\end{array}$ & Relocation benefits to owners, society, and city \\
\hline 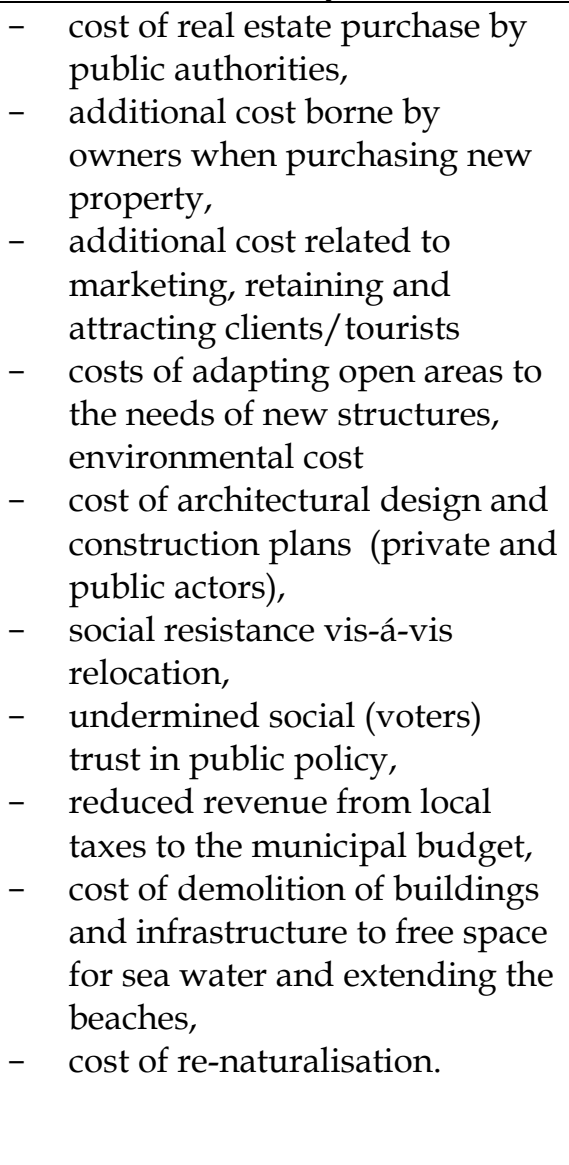 & 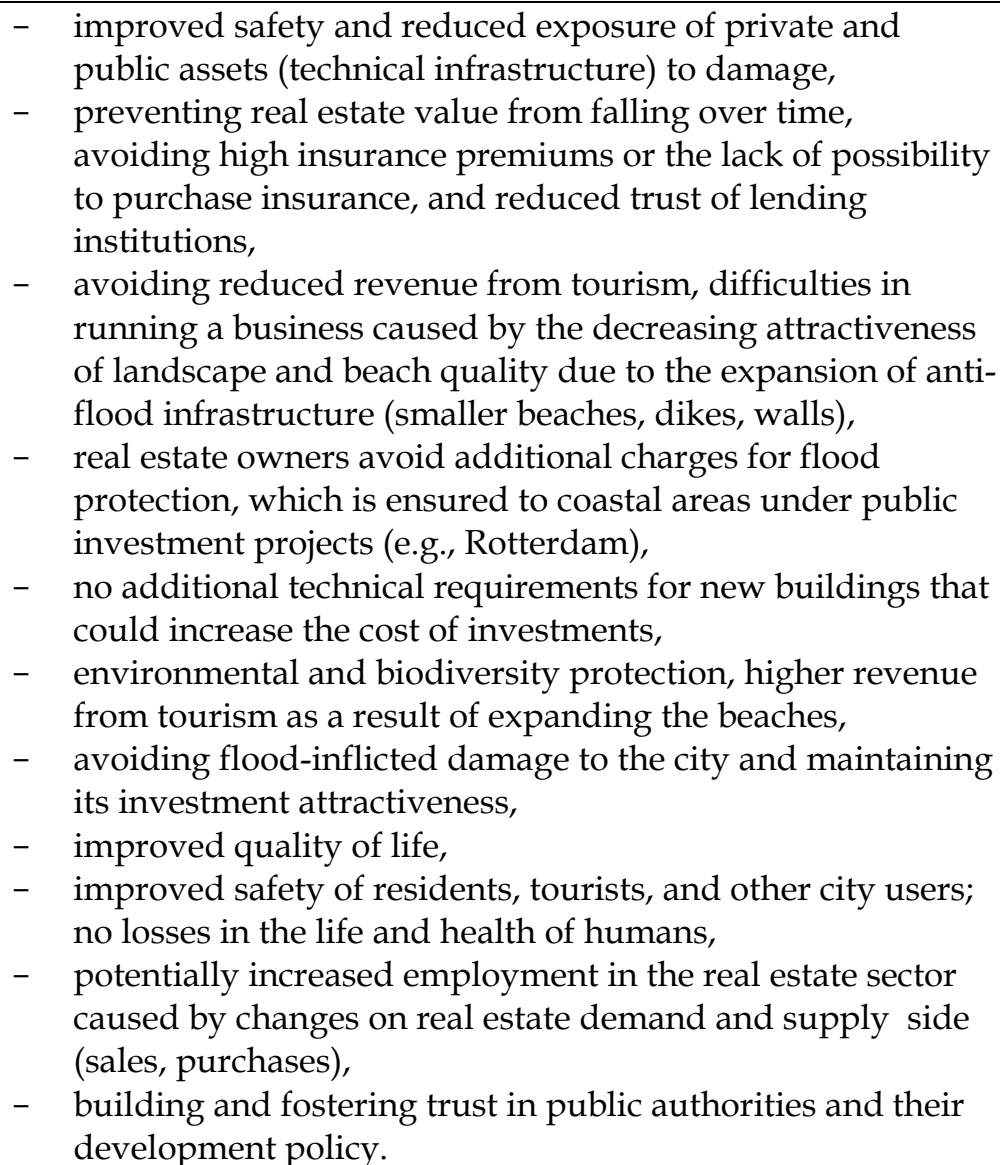 \\
\hline
\end{tabular}

Source: (Andréa et al., 2016; Bisaro \& Hinkel 2018; Nolon, 2015)

Freeing coastal areas from threatened buildings and infrastructure is becoming increasingly more important for the city and its stakeholders. Free areas open up the possibility to carry out investment projects and provide blue and green infrastructure that may foster the resilience of the city and counteract the "migration" of flood hazards (Bunten \& Kahn, 2017). The development of environmentally-friendly infrastructure improves the quality of public space in cities and offers new leisure opportunities. It has become a good practice to leave floodplains less developed to avoid high material losses. That is why these areas are used mainly as, e.g., cycling and walking routes or green areas with small architecture resilient to humidity and flooding.

Adapting real estate to climate change requires appropriate tools (strategic, operational) that must be developed at the local, regional, and central government level. We should also bear in mind barriers identified by investors and owners, which diminish their engagement in adaptation efforts, such as, e.g.: an uncertain legal environment or the absence of instruments proposed by the public sector that would promote cross-sector collaboration. There is also uncertainty as to the predicted rise in sea levels. It is quite likely that sea levels will be higher than anticipated. Under such circumstances, resilience parameters of newly designed flood infrastructure can be exceeded and, if losses occur, investors can be held liable (Bisaro \& Hinkel, 2018).

In addition to flood hazard, literature discusses the vulnerability of buildings and residents to heat. Studies have demonstrated that lower value real estate, and consequently low income populations, are much more vulnerable to extreme heat (Sagris \& Sepp, 2017). Innovation is needed to maintain heat comfort in buildings that would cater to different needs of users (Van Hoof et al., 2017; Hasegawa, 2004). 


\section{S sciendo}

The construction sector is exposed to the combination of threats triggered by climate change. Their types and intensity depend on a particular location and environmental conditions (Hasegawa, 2004). Depending on the needs, the applied solutions will be more or less capital-intensive, resourceintensive, and time-consuming.

When delivering adaptation-related investment projects, we must avoid maladaptation (Juhola, 2016). Maladaptation refers to situations where undertaken activities produce benefits to the building on the one hand, but on the other hand inflicting additional losses. An example can be planting trees near buildings (to provide shade and respond to high temperatures and urban heat islands). When there are strong winds, trees can damage buildings. Another example of maladaptation can be the use of air-conditioners on hot days to reduce indoor temperatures in buildings while hot air exhausted from air-conditioners intensifies the urban heat island effect and additional energy consumption increases greenhouse gas emissions and accelerates climate change.

Real estate climate change adaptation covers not only the adaptation of buildings, infrastructure, and urban space. It also embraces a resilient construction sector and its supply chains. Small and medium-sized enterprises should strengthen their resilience to distortions to ensure continuity of their operations and market competitiveness (Gayan et al., 2010; Wieteska, 2016). We also need new technologies and innovation supporting construction sector adaptation, new services and industries, as well as new adaptation jobs. It is a challenge to real estate administrators, property experts, SMEs, creditors, investors and developers, cross-sector collaboration, best practice exchange at international level, researchers, and society.

Some studies indicate that sustainable activities in construction improve both the adaptation and resilience of buildings (Islam, 2018). Blue and green infrastructure is an example of infrastructure that performs mitigating and adaptation functions at the same time.

Literature sources argue that climate change consequences continue to be seen as sources of low risk on the real estate market. The subject is still discussed mainly at conferences and in reports (Teicher, 2018). In fact, the issue merits much greater attention as, in cities, buildings, together with transportation networks, are the main components of urban structures. They help to meet the housing needs of residents, home businesses, cultural, sports, and health care functions, give jobs to people, and finally, provide space for local authorities responsible for the development policy, delivering their own tasks, meeting residents' needs, etc.

Gradually increasing urban stakeholders' awareness and the engagement in climate change adaptation of diverse sectors, real estate included, has become a real challenge. The issue should be mainstreamed across spatial planning, development strategies, regulations, as well as architecture and construction plans (Gayan et al., 2010).

Local authorities should develop their adaptation policy in a responsible way. In Poland, evidence of such a responsible approach can be found in urban adaptation plans.

\subsection{Real Estate in the Climate Change Adaptation Policy}

It is vital to specify the role and importance of the real estate sector in the climate change adaptation policy pursued by Polish cities and by the central government. Desk research used as a research method was helpful in this exercise.

Climate change adaptation is the leading theme of the document drafted by the Polish Ministry of Environment titled Strategiczny plan adaptacji dla sektorów i obszarów wrażliwych na zmiany klimatu do roku 2020 z perspektywa do roku 2030 [Strategic Adaptation Plan for Sectors and Areas Vulnerable to Climate Change until 2020 and an Outlook for 2030]. It delineates major adaptation measures together with sectors and areas vulnerable to climate change including:

1) the construction sector - to foster its resilience, natural hazards should be considered while designing foundations and trusses or technical installations, e.g., the sewage system;

2) the spatial economy and urbanised areas - it is recommended, inter alia, to: work out rules for the construction of buildings in areas threatened by climate change but also for green areas in cities and on the coastline; organise consultancy for investors in threatened areas; make local development plans available online; impose limits for construction projects and additional requirements linked with the protection of buildings against flooding in floodplains and in coastal zones. 
The document stresses that the most frequent effects of climate change observed in Polish cities in the real estate sector include the increased risk of damage to technical infrastructure, flooding, urban floods, and lacking continuity of water supply.

Climate change adaptation in Polish cities is becoming a vital part of an integrated, transparent, and participatory local development policy. Urban adaptation plans play a strategic, prognostic, as well as informative and educational role for entrepreneurs, investors, households, real estate owners, administrators and brokers, and public officials.

These documents highlight major issues and events that threaten residents, buildings, infrastructure, and business, and promote attitudes that embrace climate change adaptation in urban public and private spaces. Putting these into practice will reduce climate-inflicted losses, improve the resilience of buildings and society as well as the quality of life and safety, and intensify cross-sector collaboration for adaptation.

Tasks covered by MPA usually address the following building blocks (Łódź, 2018; Kraków, 2018; Wrocław, 2018; Warszawa, 2017):

1) organisation (updates of strategic and planning documents, amendments to procedures and spatial planning, public space organisation, promotion of sustainable construction through, e.g., a system of incentives for investors and developers, developing cooperation and partnership among actors engaged in adaptation and accountable for it);

2) information and education (environmental education, raising awareness of the threats and their effects, informing residents about behaviour recommended in dangerous situations, disseminating knowledge about adaptation-related solutions amongst architects, constructors, investors, developers, administrators, owners, e.g., what they can and should do about rainfall harvesting; users and people looking for flats);

3) technical (investment in green and blue infrastructure, rainwater management, development of technical infrastructure, such as, e.g. flood dikes, thermal modernisation of buildings and establishments, using renewable sources of energy, improving energy efficiency).

Having examined the MPAs of major Polish cities we could identify events posing the biggest threat to them. Such events include: extreme heatwaves, urban heat islands, increased contamination of air and smog, more frequent and intensive storms (also hail in Wroclaw), strong winds, intensified droughts, more frequent flash and pluvial floods, floods from rivers (Gdańsk, 2018; Wrocław, 2018; Warszawa, 2017) and the sea, landslides (Gdańsk, 2018), heavy snow and cold waves (Poznań, 2018).

Adaptation plans stress that intensive development of building structures, infrastructure and a growing number of investment projects have taken biodiversity away from cities, in particular from their central districts (shrinking green areas). Cities also fall short of retention capacity and adaptation potential (Gdańsk, 2018). A natural cause and effect relationship can be observed: more buildings and developing infrastructure are positive for social and economic growth of the city, however, the lack of control over the process undermines the resilience of urban areas (e.g., smaller ability to absorb rainwater, intensified urban heat islands), which, in turn, makes buildings and infrastructure more vulnerable to extreme weather events. This means that dense built-up structures and urban infrastructure (investor pressure) emerging at the cost of green areas and blue infrastructure are the main reasons of higher vulnerability of these areas to climate risk.

The following effects of extreme weather events will hinder the real estate sector (Gdańsk, 2018; Wrocław, 2018; Kraków, 2018):

1) the overheating of indoor spaces (dwellings, offices), its impact on the quality of building materials and products, soil erosion, dried soil and its effect on building foundations, impact on technical installation insulation (high temperatures);

2) underheated indoor spaces, soil solidification and its effect on foundations, impact on the quality of building materials and low frost resistant products, impact on technical installation insulation (low temperatures, cold waves);

3) inefficient sewage system of inadequate capacity, flooded buildings, basements, damp in buildings and its impact on insulation, damage to buildings and infrastructure (torrential rain);

4) higher vulnerability of the building structure over its entire lifecycle, effect on building materials and components of buildings, blown-off roofs, trees falling on buildings (extreme wind speed and snowfall);

5) damage to the facades of buildings and monuments, dirt (smog, air pollution, acid rain). 
According to local adaptation plans, the most vulnerable sectors and areas in cities include, inter alia, densely built-up housing areas, in particular compact historic and central districts of cities and modern housing districts (Gdańsk, 2018; Wrocław, 2018; Kraków, 2018; Łódź, 2018). Adapting to climate change is a long-term process filled with planning and implementation efforts. Things should be seen in perspective, especially in spatial planning, expansion of flood infrastructure, energy generation, transport infrastructure, as well as construction and housing (Warszawa, 2017). Adaptation is expected to foster the resilience of the city, including private real estate, public buildings, schools and other educational establishments, healthcare establishments, etc. (Wrocław, 2018).

MPAs represent different degrees of detail. For example, the strategy for Warsaw contains a graphic presentation of parts of the city, in which climate hazards are the lowest, medium, significant, and the highest (Warszawa, 2017). A reader is directly informed which districts, areas or investment plots are threatened with climate change and to what degree. Making a visual representation of the exposure of urban areas to climate events is often one of the tasks faced by cities (Gdańsk, 2018). Wroclaw will draft a solar map of the city, which will provide grounds for decision-making concerning the choice of technological solutions to be applied in buildings.

Urban adaptation plans pay a great deal of attention to spatial planning, in particular to the management of areas threatened with floods (Gdańsk, 2018). It is recommended to distinguish areas excluded from further development due to the high probability of floods or areas earmarked for blue and green infrastructure and flood infrastructure in local development plans. Such provisions can reduce the availability of attractive areas for housing construction or for building warehouse and logistic facilities. Spatial planning will focus on promoting and using green roofs and walls, rain gardens, green areas, trees, restoring retention capacity (concrete encasement of industrial, postindustrial, and densely built-up areas), and sustainable water management based on the principle collect, retain, use, and discharge. Building a compact city and counteracting suburbanisation become the priority. The focus on building a compact city and preventing urban sprawl will diminish opportunities for greenfield investment and may shift construction efforts to urbanised areas and promote brownfield investment projects (Warszawa, 2017; Wrocław, 2018).

The list of actors involved in climate change adaptation in cities includes public authorities, residents, and businesses (Poznań, 2018). Participation of all stakeholders, their collaboration and commitment guarantee effective and efficient adaptation of the city to climate change. Urban adaptation plans must be implemented by owners of buildings, their users and administrators. Activity areas include, e.g., the development of green infrastructure, ventilation corridors in urban areas, changing to more efficient heating and cooling systems, thermal modernisation, bright facades, modernisation of buildings to ensure higher thermal comfort to residents, energy efficiency, development of green and blue infrastructure, water and sewage management, rainwater management (Gdańsk, 2018; Poznań, 2018). Thus, we need to mobilise and use private funds, financial resources of cities, housing cooperatives, housing communities, enterprises, and external sources of funding (operational programmes, EU Framework Programme Horizon 2020, Financial Mechanism LIFE, NFOŚiGW resources) (Warszawa, 2017).

Like any other strategy, the structure of MPA covers the expected outcomes of tasks measured with appropriately selected indicators supposed to either increase or decrease. Some of these indicators concern the real estate sector:

1) Proportion of decisions specifying terms for construction and management issued for built-up areas, which provide for the inclusion of elements of green and blue infrastructure;

2) Area covered by the local development plan designated to protect natural assets/predispositions for the system of blue and green infrastructure;

3) Multifamily dwellings subject to thermal modernisation (Łódź, 2018);

4) Buildings connected to the heating or gas supply system and elimination of solid fuel heating sources;

5) People living within the range exceeding $300 \mathrm{~m}$ from urban green leisure areas as a proportion of total population;

6) Drafting a Good Practice Catalogue for blue and green infrastructure for housing cooperatives and individual real estate owners (Poznań, 2018);

7) Green areas available to residents per km² (Gdańsk, 2018); 
8) Area and number of blue and green infrastructure elements (e.g., springs, fountains, parks) (Gdańsk, 2018);

9) Buildings with eco-construction certificates (Wrocław, 2018).

MPAs also highlight opportunities for the real estate sector triggered by the climate change, such as: advancing innovation in heating technologies and thermal insulation, improved access to modern solutions and their lower cost, developing building technologies in the area of resilience to high temperatures (proper shading, blinds, reduced visual light transmission, etc.); reduced average energy demand in the heating season (lower costs to recipients, lower investment cost of expanding the heat transmission network); expansion of blue and green infrastructure that improves the overall aesthetics, quality of life, and attractiveness of cities to its residents; better access to green areas and retention tanks, which can increase real estate value; improved rainwater management, reduced water consumption for, e.g., for watering plants; reduced volume of waste water and lower cost of rain tax; shortening of the heating season; extended season for repairs and construction works; lower cost of snow removal (Poznań, 2018; Wrocław, 2018; Kraków, 2018).

\section{Discussion}

Recent years have witnessed an increasing number of subject-matter literature that discusses the real estate market in the context of climate change adaptation. Most publications focus on coastal real estate threatened by the sea and rising sea levels. Studies focus on the identification of costs, benefits, and barriers to the adaptation of buildings. However, there is still a visible shortage of research studies, identified good practices, possibilities to get support for adopting adaptation measures from public authorities, and little collaboration under the public-private partnership format.

Occurrences threatening the real estate sector in cities may differ due to the specificity of natural conditions. Such events may contribute to material and non-material losses in real estate. Climate change adaptation policy includes provisions that can boost real estate performance and impact real estate market participants. Proper spatial planning at local levels has significantly gained in importance. Amendments to spatial planning regulations may exacerbate requirements posed vis-ávis investors with regard to the protection of buildings against weather events, rainwater management, excluding endangered areas from investment, and earmarking attractive areas for blue and green infrastructure. Over a longer term, climate change adaptation can require adjusting building regulations with respect to: insulation norms, ventilation, air-conditioning, supporting structures, wind and snow loads, or installation design (Kochańska, 2014).

Warsaw Housing Standard [PL: Warszawski Standard Mieszkaniowy] (Biuro Polityki..., 2018) is an innovative document. It is a collection of rules, which, if applied, should result in high quality housing resources. Recommendations include guidelines concerning the adaptation of housing to climate change. It is recommended to take climate hazards into account in investment projects and apply adaptation solutions, as well as investigate the effect of investments on the local urban climate.

MPA content refers directly to the real estate sector. Many measures projected in documents are intended to additionally foster the resilience of buildings and improve safety. For instance, higher resilience of cities to energy and water outages will bring forward the resilience of buildings, and provide operational continuity to households, enterprises, and public offices. Proper functioning and ensuring stability to operations has a bearing on financial capacity of tenants and their ability to, e.g., timely pay the rent. Attractive and safe housing and office space improves the attractiveness of urban areas.

The delivery of measures planned under the MPA will improve the quality of water, waste water, and energy management, flood, blue and green infrastructure, and the protection of crucial urban infrastructure. It will translate into the continuity of operations of enterprises, public establishments, and the performance of households. This also means that overall safety in cities improves, together with attaining a higher quality of life and investment attractiveness. However, we need to bear in mind that adaptation depends on political, economic, social, cultural, and technological circumstances in cities, countries and in the European Union. This is why the engagement of all levels of governance in an integrated development policy favouring climate change adaptation is necessary. Only with such engagement of all interested parties can maximum benefits be achieved, producing economic, social, and environmental effects of adaptation efforts. 
Increased interest in climate change adaptation can add on dynamics to the creation of innovation in the area of the adaptation of buildings and public space, increase employment and growth, give better access to innovation and reduce financial barriers to the absorption of modern solutions in buildings (Wieteska-Rosiak, 2017).

A building is an establishment exposed to changes in its environment and, at the same time, exerting an impact on its surroundings. This is why there are different relationships that develop between the building and its environment (Firlagg, 2018). Among them we can find relations which strengthen resilience. Construction of blue and green infrastructure in the city and resilient public space increase the resilience of buildings and real estate. Simultaneously, sustainable water management in buildings, a growing number of green roofs and walls, green areas, and using renewable energy sources make public space and neighbouring buildings more resilient. Parallel activities pursued in public and private space are complementary and improve the resilience of the entire city creating a resilient social and economic system. Growing and better access to green areas in cities resulting from the implementation of climate change policy can contribute to a higher attractiveness of housing resources and their market value.

Irrespective of climate change disadvantages and the need to involve diverse stakeholders in the city in undertaking a number of activities, there are also potential opportunities resulting from climate change. If used appropriately, these opportunities can reinforce and dynamize the social and economic growth of a city. Adaptation of urban building stock can help in creating climate change adaptation jobs and reveal new business areas aimed at strengthening, inter alia, the resilience of buildings and urban space. It is expected that real estate brokers, as well as occupations in construction, engineering and consulting industries will benefit the most from climate change (European Commission, 2014). Climate change adaptation will contribute to increased employment in the real estate sector, also in its valuation section. At the same time, climate change adaptation can reduce employment and generate problems for tourist and leisure establishments in mountain areas. The on-going promotion of adaptation solutions highlights the key role played by architects, constructors, fitters, investors, developers, and customers. What we need is the accumulation of knowledge about and rising awareness of climate change in all real estate sector stakeholders.

There are still concerns and uncertainty over climate change and how it will evolve. This means that the rationale behind large infrastructural investment projects can be questioned (cost and benefit analysis). Many investment projects planned under the MPA are not as capital-intensive as, e.g., the construction of a sea water desalination plant. There are many soft investment projects of an organisational, educational, and informative nature. The accomplishment of tasks engages various stakeholders without burdening the resources (financial, human) or the private and public sector. On the contrary, it generates highly complementary activities and increases the likelihood of the successful delivery of the planned adaptation policy.

Identification of highly threatened areas in the city (risk maps) raises the question of whether it translates into the scale of spatial distribution of investment projects across the city, e.g., as a result of the reluctance to invest and live in endangered areas. On the other hand, the most threatened areas are a high priority on local authorities' adaptation policy agendas. Over a longer period, carrying out urban investment projects can increase the interest of investors and residents in these areas. Adapted cities can attract investors with the low risk of damage, growing quality of life and, possibly, increasing demand for housing, office, and commercial spaces.

Further questions so far left without precise answers are also: how does climate change adaptation impact the demand, supply, and value of real estate in the city; how long does it take for an adaptation policy to impact the environmental awareness of residents and change their preferences as to the choice of buildings; how aware are architects and constructors of climate change adaptation; how will the growing relevance of the adaptation policy impact the development of innovation, new occupations and firms rendering services in this area; what will the pace of activities in individual cities be; can the adaptation policy become a component of the competitive advantage of a city and its businesses; what is the model of climate change adaptation of a building throughout its entire lifecycle; what solutions proposed for buildings act to mitigate climate change and, at the same time, adapt them to distortions?

These and other questions can also be seen as directions for further research in the field of climate change adaptation of the real estate sector. This only confirms the need to continue investigation into 
climate change adaptation of the real estate sector in Polish cities, in the EU and at an international level.

\section{Conclusions}

Research methods used in the studies helped to accomplish the goal of the work, which was to give answers to research questions and validate the research hypothesis.

The systematic analysis of literature answered research question 1 . Desk research methodology provided answers to research questions 2,3, and 4 . The conducted studies enabled the formulation of the most important conclusions:

1. Subject-matter literature exhibits a growing interest in the real estate sector in the context of climate change adaptation.

2. Subject-matter literature is dominated with real estate climate change adaptation issues encountered in coastal regions, as well as costs, benefits, and barriers to real estate adaptation.

3. There is a gap in the identification of good practices in real estate climate change adaptation.

4. Extreme weather events specified in MPA, which pose a threat to real estate, include, inter alia: high temperatures, the urban heat island effect, low temperatures and cold waves, torrential rain, extreme wind speeds, and air pollution.

5. Intensification of threats can potentially increase material and non-material damage to real estate, e.g., buildings, green areas, technical infrastructure, reduced productivity, and housing quality.

6. The following soft and hard instruments are critical to the adaptation policy, e.g.:

- proper spatial planning (construction restrictions in endangered areas, the growth of blue and green infrastructure, green roofs in investment projects),

- incentives for investors and developers to promote sustainable construction and adaptation measures;

- environmental education and raising awareness about the need of climate change adaptation in real estate among architects, constructors, investors, developers, and administrators,

- investing in thermal modernisation of buildings and establishments, use of renewable energy sources, and improved energy efficiency of buildings.

7. Besides the negative effects of climate change, there are also potential benefits for the real estate sector, such as, e.g., increased importance of occupations that belong to the real estate sector (brokers, valuation experts, constructors, engineers, and consultants), the emergence of adaptation jobs, advancing innovation and better access to new and cheaper technologies and services.

8. Local development policy realises the need of climate change adaptation in buildings, which is confirmed by urban adaptation plans and the Warsaw Housing Standard.

9. Urban adaptation plans indicate a significant role of the real estate sector in climate change adaptation.

10. Highly vulnerable areas in Polish cities are intensively built-up housing districts (compact groupings of historic houses and the city centre; modern housing districts).

11. Strengthening the resilience of technical infrastructure, e.g., energy transmission networks in cities, strengthening the resilience of real estate, ensuring stability for business, provision of public services, and the improving the quality of life of residents.

12. Climate change adaptation in public spaces and the development of blue and green infrastructure improve real state resilience by reducing its vulnerability to climate change.

13. Higher resilience of urban buildings increases the resilience of the entire city, improves their investment attractiveness and competitiveness, as well as the quality of life of residents. Potentially, the aforesaid can increase the attractiveness of real estate and demand for it.

Summing up, the research hypothesis proposed in this work: Increased prominence of adaptation policy and the intensity of occurrences increase the role of the real estate sector in climate change adaptation of urban areas has been positively validated. The role and relevance of the real estate in climate change adaptation in urban areas are increasingly gaining in importance. Adequate climate change adaptation in cities calls for the engagement of the real estate sector in adaptation efforts. The synergy of measures adopted in the public and private sectors can unleash a dynamic increase in the resilience of the entire urban system. 


\section{Bibliography}

André, C., Boulet, D., Rey-Valette, H., \& Rulleau, B. (2016). Protection by hard defence structures or relocation of assets exposed to coastal risks: Contributions and drawbacks of cost-benefit analysis for long-term adaptation choices to climate change. France Ocean \& Coastal Management, 134, $173-$ 182. https:// doi.org/10.1016/j.ocecoaman.2016.10.003.

Binbin, P., Jie, S. (2018) Case Study of Preliminary Cost-Benefit Analysis of Building Levees to Mitigate the Joint Effects of Sea Level Rise and Storm Surge. WATER, 10(2), Article Number: 169.

Bisaro, A., \& Hinkel, J. (2018). Mobilizing private finance for coastal adaptation: A literature review. Wiley Perdications WIREs Clim Change, 9, e514. https://doi.org/10.1002/wcc.514

Biuro Polityki Lokalowej Miasta Warszawy. (2018). Warszawski standard mieszkaniowy 1.2 (projekt do konsultacji); pp. 40-41; as at 1.12.2018.

Bunten, D., \& Kahn, M. (2017). Optimal real estate capital durability and localized climate change disaster risk [EBSCO]. Journal of Housing Economics, 36, 1-7. https://doi.org/10.1016/j.jhe.2017.01.004.

Chouinard, O., Rabeniaina, T., \& Weissenberger, S. (2013). Learnings on Coastal Planning in Two Territories of New Brunswick's Acadian Coast Vulnerable to Erosion and Flooding. OpenAIRE Études Caribéennes, 26, 1-8.

Darwin, R. (1999). A farmer's view of the Ricardian approach to measuring agricultural effects of climatic change. Climatic Change, 41(3-4), 371-411. https:/ / doi.org/10.1023/ A:1005421707801

Denyer, D., \& Tranfield, D. (2009). Producing a Systematic Review, Buchanan D., Bryman A. (ed.), The Sage Handbook of Organizational Research, Sage Publications, London, pp. 671-689.

European Commission. (2019). A Clean Planet for all A European strategic long-term vision for a prosperous, modern, competitive and climate neutral economy. European Commission.

European Commission. 2014, Assessing the Implications of Climate Change Adaptation on Employment in the EU, pp. 1-55; https://ec.europa.eu/clima/sites/clima/files/adaptation/what/ docs/climate_change_employment_eu_en.pdf as at 01.12.2018.

Firląg, S. (Ed.). (2018). Zrównoważone budynki biurowe. PWN.

Hasegawa, T. (2004). Climate change, adaptation and government policy for the building sector. Building Research and Information, 32(1), 61-64.

Fu, X., Song, J., Sun, B., \& Peng, Z. (2016). Living on the edge: Estimating the economic cost of sea level rise on coastal real estate in the Tampa Bay region, Florida. Ocean and Coastal Management, 133, 11 17. https://doi.org/10.1016/j.ocecoaman.2016.09.009.

Gayan, W., Bingunath, I., \& Dilanthi, A. (2010). Building up resilience of construction sector SMES and their supply chains to extreme weather events. International Journal of Strategic Property Management, 14(4), 362-375. https://doi.org/10.3846/ijspm.2010.27.

Gdańsk. (2018), Plan adaptacji miasta Gdańska do zmian klimatu do roku 2030. Projekt https:// www.gdansk.pl/download/2018-11/117491.pdf; pp. 1-58; as at 1.12.2018.

Islam, M. (2018). Business Adaptation to Climate Change: A Case Study in Bangladesh. Global Business and Management Research, 10(2), 41-51.

Ipcc, Intergovernmental Panel on Climate Change, 2018, Global Warming of 1,5 ${ }^{\circ}$. Summary for policy makers, Intergovernmental Panel on Climate Change, https://report.ipcc.ch/sr15/pdf/ sr15_spm_final.pdf as at 19.07.2019.

Juhola, S., Glaas, E., Linnér, B. O., \& Neset, T. S. (2016). Redefining maladaptation. Environmental Science \& Policy, 55(Part 1), 135-140. https:// doi.org/10.1016/j.envsci.2015.09.014.

Keenan, J. M., Hill, T., \& Gumber, A. (2018). Climate gentrification: From theory to empiricism in Miami-Dade County, Florida. Environmental Research Letters, 13, 054001. https:// doi.org/10.1088/1748-9326/aabb32.

Kochańska, E. (Ed.). (2014). Determinanty rozwoju odnawialnych źródeł energii, Centrum Badań i Innowacji Pro-Akademia, p. 11; http://www.proakademia.eu/gfx/baza_wiedzy/397/ monografia-determinanty-rozwoju-oze-www.pdf, as at 01.12.2018.

Kraków. (2018). Plan adaptacji miasta Krakowa do zmian klimatu do roku 2030. Projekt. 1-83; https://ngo.krakow.pl/zalacznik/319113 as at 01.12.2018.

Łódź. (2018). Plan adaptacji do zmian klimatu miasta Łodzi do roku 2030; 1-58; https://bip.uml.lodz.pl/files/bip/public/BIP_AB/WOSR_klimat_pro_181003.pdf as at 01.12.2018. 
McAlpine, S. A., \& Porter, J. R. (2018). Estimating Recent Local Impacts of Sea-Level Rise on Current Real-Estate Losses: A Housing Market Case Study in Miami-Dade, Florida. Population Research and Policy Review, 37, 871-895. https:// doi.org/10.1007/s11113-018-9473-5 PMID:30546178.

McNamara, D. E., \& Keeler, A. (2013). A coupled physical and economic model of the response of coastal real estate to climate risk. Nature Climate Change, 3(6), 559-562. https://doi.org/10.1038/nclimate1826.

McNamara, D. E., Smith, M. D., \& Murray, A. B. (2015). Climate Adaptation and Policy-Induced. Inflation of Coastal Property Value, PLoS ONE, 10(3), 1-12.

Ministerstwo Infrastruktury i Rozwoju. (2015). Krajowa Polityka Miejska 2023, 89-95.

Ministerstwo Rozwoju Regionalnego. (2012). Strategia Rozwoju Kraju 2020, 214.

Ministerstwo Środowiska. (2013). Strategiczny plan adaptacji dla sektorów i obszarów wrażliwych na zmiany klimatu do roku 2020 z perspektywą do roku 2030, 30-32.

Nolon, J. R. (2015). Land Use and Climate Change Bubbles: Resilience, Retreat, and Due Diligence [EBSCO]. William and Mary Environmental Law and Policy Review, 39(2), 321-364.

Marengo, J. A., Nunes, L. H., Souza, C. R. G., Harari, J., Muller-Karger, F., Greco, R., Hosokawa, E. K., Tabuchi, E. K., Merrill, S. B., Reynolds, C. J., Pelling, M., Alves, L. M., Aragão, L. E., Chou, S. C., Moreira, F., Paterson, S., Lockman, J. T., \& Gray, A. G. (2017). A globally deployable strategy for co-development of adaptation preferences to sea-level rise: The public participation case of Santos, Brazil. Natural Hazards, 88(1), 39-53. https:/ / doi.org/10.1007/s11069-017-2855-x.

Poznań. (2018) Plan adaptacji do zmian klimatu Miasta Poznania do roku 2030, as at 1.12.2018, 1-75.

Rutty M., Scott D. Johnson P., Jover E., Pons M., Steiger R. (2015). Behavioural adaptation of skiers to climatic variability and change in Ontario, Canada. Journal of Outdoor Recreation and Tourism, 11, 1321. https:// doi.org/10.1016/j.jort.2015.07.002.

Sagris, V., \& Sepp, M. (2017). Landsat-8 TIRS Data for Assessing Urban Heat Island Effect and Its Impact on Human Health. IEEE Geoscience and Remote Sensing Letters, 14(12), 2385-2389. https://doi.org/10.1109/LGRS.2017.2765703.

Scott, D., Dawson, J., \& Jones, B. (2008). Climate change vulnerability of the US Northeast winter recreation- tourism sector. Mitigation and Adaptation Strategies for Global Change, 13(5-6), 577-596. https://doi.org/10.1007/s11027-007-9136-z .

Teicher, H. M. (2018). Practices and pitfalls of competitive resilience: Urban adaptation as real estate firms turn climate risk to competitive advantage. Urban Climate, 25, 9-21. https:// doi.org/10.1016/j.uclim.2018.04.008.

Warren-Myers, G., Aschwanden, G., Fuerst, F., \& Krause, A. (2018). Estimating the Potential Risks of Sea Level Rise for Public and Private Property Ownership, Occupation and Management. RISKS, 6(2), 37. https://doi.org/10.3390/risks6020037

Tranfield, D., Denyer, D., \& Smart, P. (2003). Towards a methodology for developing evidenceinformed management knowledge by means of systematic review. British Journal of Management, 14(3), 207-222. https:// doi.org/10.1111/1467-8551.00375.

Warszawa. (2017). Strategia adaptacji do zmian klimatu dla m.st. Warszawy do roku $2030 \mathrm{z}$ perspektywą do roku 2050. Założenia do konsultacji, 1-44; http://adaptcity.pl/wpcontent/uploads/2017/02/Warszawska-Strategia-

Adaptacji_za\%C5\%82o\%C5\%BCenia_upowszechnianie.pdf as at 01.12.2018.

Wieteska, G. (2016). Building resilient relationships with suppliers in the B2B market. Management, 20(2), 307-321. https:// doi.org/10.1515/manment-2015-0067.

Wieteska-Rosiak, B. (2017). Kierunki rozwoju gospodarczego miast $\mathrm{w}$ perspektywie adaptacji do zmian klimatu. Studia Ekonomiczne. Zeszyty Naukowe Uniwersytetu Ekonomicznego w Katowicach, 320, 61-74.

Wroctaw. (2018). Plan adaptacji Miasta Wrocław do zmian klimatu do roku 2030. Projekt, 1-151; http:// bip.um.wroc.pl/artykul/528/36151/plan-adaptacji-miasta-wroclaw-do-zmian-klimatu-doroku-2030; as at 1.12.2018.

van Hoof, J., Schellen, L., Soebarto, V., Wong, J. K. W., Kazak, J. K., \& the VAN Hoof J. (2017). Ten questions concerning thermal comfort and ageing. Building and Environment, 120, 123-133. https://doi.org/10.1016/j.buildenv.2017.05.008.

Veelen, P. C. (2016). Adaptive, Planning for Resilient Coastal Waterfronts. Delft University of Technology, $A+B E$ : Architecture and the Built Environment, 19, 1-248. 